\title{
Comparative Analysis of Certain Morphological Characteristics of Top Tennis Players in Different Periods
}

\author{
Jovanka Mimic ${ }^{1}$, Veljko Vukicevic ${ }^{1}$, Nadja Vujacic ${ }^{1}$ \\ 'University of Serbia, Faculty of Sport and Physical Education, Novi Sad, Serbia
}

\begin{abstract}
An interdisciplinary approach to solving the issue of professional tennis playing is all the more becoming a condition for further development and planning regarding the sport. The aim of this study is to determine statistically relevant differences among top tennis players over the various periods expressed in the measures used for assessing morphological characteristics. A survey has been conducted with the objective of putting a bigger focus on the selection of tennis players based on body height, body mass, BMI and the age in various periods of tennis playing. The sample of respondents consisted of 50 tennis players for a period of 40 years. Data were taken regarding 10 most successful tennis players for the respective year on the account of their ATP ranking. The results derived from the univariate analysis of variance indicated that the examinees from various periods of playing tennis differentiated among each other with respect to body mass, nutrition state and years of age. Examinees from a group of tennis players active in 1986, on average had better and statistically more relevant BMI values when compared to the examinees from the 2006 group and 2016 group. Moreover, it was noted that the examinees from 1986 were statistically younger in relation to the examinees from 2016. It can be assumed that for successful tennis playing in the last decade certain experience is required, as well as age, including body mass which needs to be slightly bigger, but to the advantage of muscle mass.
\end{abstract}

Key words: Tennis Players, Morphology, Differences, Selection

\section{Uvod}

Razvoj i napredak vrhunskog tenisa uslovljen je naučnim pristupom toj problematici (Crespo \& Miley, 1999). Interdisciplinarni pristup rješavanja problema vrhunskog bavljenja tenisom postaje sve više uslov za dalji razvoj i planiranje tog sporta, jer bez saradnje sa drugim naukama, upoređivanjem rezultata između grupa i pojedinaca, ne postoji mogućnost postizanja vrhunskih rezultata (Roetert, 2003). Izrazita dinamika i brzina, igre kao i sve veći broj mladih tenisera uključenih u programe sportskog treninga i takmičenja zahtijevaju odličnu fizičku pripremljenost tih sportista i visok nivo funkcionalnih sposobnosti perspektivnih igrača (Saavedra et al., 2018). Naravno, u vrhunskom tenisu većina trenera obraća pažnju i na statističke pokazatelje svojih igrača nakon meča, kao i za vrijeme njegovog toka. Tenis je polistrukturalna aktivnost sa acikličkim tipom kretanja koja je tokom godina evaluirala i postala moderna sportska igra u kojoj sportisti posjeduju atletski izgled. Nastale situacije u teniskoj igri (tehničkih i taktičkih varijanti) ukazuju da je uspješnost tenisera određena nivoom i strukturom velikog broja motoričkih sposobnosti, morfoloških karakteristika, znanja i osobina od kojih se neke mogu izmjeriti i analizirati pa potom evaluirati sa standardima. Mjerenje tih sposobnosti i osobina omogućuje kvalitetnije planiranje, programiranje i kontrolu trenažnog procesa te poboljšanje sportske forme.

Dijagnostika u sportu, pa tako i u tenisu, podrazumijeva prikupljanje upotrebljivih informacija o inicijalnom, tranzitivnom i finalnom stanju sportista u prostoru sposobnosti i osobina koje su bitne za uspješnost u takmičarskom sportu (Guyton, 2006; Popovic, Akpinar, Jaksic, Matic, \& Bjelica,

\section{Montenegro}

Sport

\section{Correspondence:}

V. Vukicevic

Faculty of Sport and Physical Education, Lovćenska 16, 21000 Novi Sad, Serbia

E-mail: vukicevicveljko9@gmail.com 
2013). Važno je izmjeriti i utvrditi one sposobnosti, osobine ali i parametre uspješnosti, koje znatno učestvuju u jednačini uspjeha u određenoj sportskoj disciplini (Masanovic, Milosevic, \& Corluka, 2018), a u našem slučaju vezano za tenis, koji postaje sve popularniji u našoj zemlji, kako bismo što ranije otkrili talentovanu djecu i omladinu za ovaj sport.

Vrhunska sportska dostignuća rezultat su čitavog niza različitih faktora, od nasljeđa do sportskog treninga i sistema takmičenja (Arifi, Bjelica, \& Masanovic). U tenisu je većina dobrih i slabih karakteristika i motoričkih sposobnosti igrača, u prvom redu posljedica određenog načina treniranja i cjelokupnog trenažnog i takmičarskog procesa. Međutim, jedan broj karakteristika i sposobnosti je određen tjelesnom konstitucijom igrača (Bala, 1997; Armenulić, 2001; Fernandez, Mendez-Villanueva, Pluim, 2006).

Optimalne morfološke karakteristike sportista u velikoj mjeri zavise od izabranog sporta, međutim, generalno bolje rezultate postižu oni čija je građa tijela prilagođena zahtjevima određenog sporta (Popovic, Bjelica, Jaksic, \& Hadzic, 2014; Masanovic, Corluka, \& Milosevic, 2018). Potreba za navedenim prilagođavanjem izraženija je što je sportista na višem takmičarskom nivou (Vukasevic, Spaic, \& Masanovic, 2018). Uspjeh u tenisu svakako zavisi i od morfoloških karakteristika formiranog tenisera, od kojih su osnovne tjelesna visina i masa, a koje se valoriziraju s obzirom na trenutni uzrast tenisera (Girard \& Millet, 2004). Posebno u zadnjih desetak godina, utvrđena je vrlo uska povezanost između morfoloških karakteristika tenisera i njihovih takmičarskih uspjeha (Friščić, 2004). Tjelesna građa nije isključivo uslov za uspijeh, ali je u svakom slučaju faktor koji će odrediti stil igre pojedinca (Castellani, D’Aprile, \& Tamorri, 1992; Novak, Milanović, i Barbaros-Tudor, 2015). Na osnovu građe svojih igrača, kvalitetni će teniski treneri znati u trenažnom procesu naglasiti one elemente tehnike i taktike koje će omogućiti da igrač postigne svoj takmičarski maksimum, optimalno koristeći svoje karakteristike. Rezultati sprovednih istraživanja ukazuju na statistički značajne razlike među mladim teniserima Hrvatske. Značajne razlike su dobijene u većini posmatranih mjera za procjenu morfoloških karakteristika, ali se najznačajnije razlike ogledaju u varijabli za procjenu longitudinalne dimenzionalnosti skeleta, tjelesne mase i voluminoznosti tijela. Studija je pokazala da se ovi parametri moraju posmatrati u perspetkivi razvoja mladih tenisera jer se selekcija i u ovom sportu počinje zasnivati na izraženim morfološkim karakteristikama (Novak i sar., 2015). Kada bi željeli definisati prototip tenisera, obavezno bi morali uvažiti sljedeće parametre, raspon gornjih ekstremiteta (ruku) pojedinca bi trebao biti veći od njegove visine, visina tijela bi trebala biti iznad prosječnih vrijednosti (Janković, 2011). Već ova dva parametra daju jednu hipotetsku sliku idealnog tenisera. Prednosti ovako koncipirane tjelesne strukture su evidentne u svakoj fazi igre, te su naučno objašnjive elementarnim principom mehanike, a to je ugaona brzina. Pojednostavljeno, ovaj princip govori sljedeće: što je poluga podvrgnuta ugaonoj brzini duža, to će linearna brzina biti veća na ekstremitetu te iste poluge. Ovaj mehanički zakon je primjenjiv na svim osnovnim udarcima u tenisu (Janković, 2011). Istraživanja ukazuju na postojanje razlika u morfološkom prostoru između elitnih tenisera juniorskog uzrasta koji su najviše rangirani i tenisera slabijeg ranga. Najveće razlike uočavaju se u obimu nadlaktice, natkolenice i tjelesnoj visini kako u muškoj, tako i u ženskoj konkurenicji (Sánchez-Muñoz, Sanz, \& Zabala, 2007). Za tenisere je danas najprihvatljivija Kretschmerova klasifikacija (1921) koja kaže da se sportski tip tenisera i pored svoje vitkosti i atletske konstitucije sve više približavaju leptosomnom konstitucionalnom tipu. Prema toj klasifikaciji dominantna je visina, a svi ostali parametri obima i širine (osim obima podlaktice dominanthe ruke), a time i čitavog tijela, su mali. Osobe ovog tipa su vitke, gracilnog skeleta, uzanih ramena, dok je grudni koš dug, uzan od naprijed, nazad pljosnat, te je epigastrični ugao oštar. Mišići su kao i udovi dugi i tanki, lice izduženo, nos dug i uzan, brada slabo izražena, a vrat tanak i dug.

Cilj istraživanja je utvrđivanje statistički značajne razlike između vrhunskih tenisera (vodećih 10 na ATP listi) u različitim vremenskim periodima (1973. - 2016. godine) u mjerama za procjenu morfoloških karakteristika, kao i da se na osnovu rezultata ukaže na potrebu većeg akcentovanja selekcije tenisera na osnovu pojedinih morfoloških karakteristika.

\section{Metod}

Uzorak ispitanika čine teniseri koji su se prema zvaničnim podacima ITF nalazili u prvih deset na ATP listi u period između 1973-2016. Prvih deset tenisera iz 1973. godine (prvih 10 na ATP listi za tu godinu) su činili prvu grupu

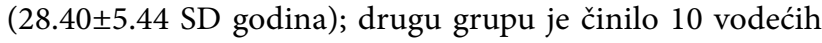
tenisera (24.10 $\pm 4.25 \mathrm{SD}$ godina) iz 1986. godine (prvih 10 na ATP listi za tu godinu); treće grupu je sačinjavalo prvih 10 na ATP listi za 1996. godinu (25.20 \pm 2.39 SD godina); četvrtu grupu je činilo prvih 10 na ATP listi za 2006. godinu $(24.40 \pm 2.17$ SD godina); petu grupu ispitanika činilo je prvih 10 tenisera na ATP listi za 2016. godinu (30.30 \pm 2.79 SD godina).

Metod rada koji je korišćen podrazumijevao je ravnopravan tretman empirijskih i teorijskih istraživanja, $\mathrm{tj}$. induktivni i deduktivni pristup u zaključivanju. Prema prirodi naučnih istraživanja, ovo istraživanje pripada kategoriji empirijskih, dok prema cilju preduzimanja predstavlja primijenjeno, odnosno aplikativno istraživanje koje ima za cilj sticanje novih znanja i informacija potrebnih za praktičnu primjenu u oblasti tenisa, a šire posmatrano, i u nastavnoj praksi u vaspitnoobrazovnim institucijama, Morfološke karakteristike vrhunskih tenisera preuzete su sa zvaničnog sajta ATP-a. Rezultati sprovedenog istraživanja su podijeljeni na dva djela: predstavljanje deskriptivnih karakteristika analiziranih mjera za procjenu morfoloških karakteristika, kao i rezultata razlika između grupa u mjerama za procjenu morfoloških karakteristika. Ukupno su u istraživanju bili korišćeni osnovni podaci za 50 tenisera u rasponu od 40 godina. Za procjenu morfoloških karakteristika izabrane su sljedeće antropometrijske mjere: tjelesna visina $(\mathrm{cm})$ - za procjenu longitudinalne dimenzionalnosti skeleta, tjelesna masa $(\mathrm{kg})$ - za procjena mase tijela, i body mass index - BMI $(\mathrm{kg} / \mathrm{m} 2)$. Kao još jedan bitan parametar uzeta je starost tenisera na kraju kalendarske godine. Podaci za ovo istraživanje su preuzeti sa zvaničnog sajta ATP-a. Preuzeti su podaci o dostupnim morfološkim karakteristikama za 10 vodećih tenisera za 1973., 1986., 1996., 2006. i 2016. godinu u pojedinačnoj muškoj (singl) konkurenciji. BMI je naknadno izračunat, a kategorizacija stanja uhranjenosti izvršena je na osnovu Harisonove kategorizacije (Kristiforović-Ilić, 2004) i prikazana u tabeli 1 , odnosno na grafikonu 1 . 
Tabela 1. Kategorizacija BMI prema Harisonu (Kristiforović Ilić, 2004)

\begin{tabular}{cc}
\hline Ocjena BMI & $\mathbf{k g} / \mathbf{m}^{\mathbf{2}}$ \\
\hline BMI & Kategorija \\
$<16$ & Ozbiljna pothranjenost \\
$16-16.9$ & Srednja pothranjenost \\
$17-18.4$ & Umjerena pothranjenost \\
$18.5-24.9$ & Normalan obim uhranjenosti \\
$25-29.9$ & Prekomjerna težina \\
$30-39.9$ & Gojaznost \\
$>40$ & Patološka gojaznost \\
\hline
\end{tabular}

Podaci dobijeni istraživanjem obrađeni su postupcima deskriptivne i komparativne statističke procedure. Za svaku varijablu su obrađeni centralni deskriptivni parametri kao što su: aritmetička sredina (AS), standardna devijacija (S) minimalne (MIN) i maksimalne (MAX) vrijednosti rezultata mjerenja, koeficijent varijacije (CV), normalnost distribucije (Shapiro Wilk test). Od metoda komparativne statistike pri- mijenjena je univarijatna analiza varijanse (ANOVA) - da bi se utvrdilo postojanje statistički značajne razlike između grupa, i Bonferonijev test - da bi se utvrdilo tačno između kojih grupa postoje statistički značajne razlike. Podaci su izračunati korišćenjem softverskog paketa za obradu podataka SPSS 20.0. Nakon obrade podataka rezultati su prodiskutovani i izvedeni su zaključci.

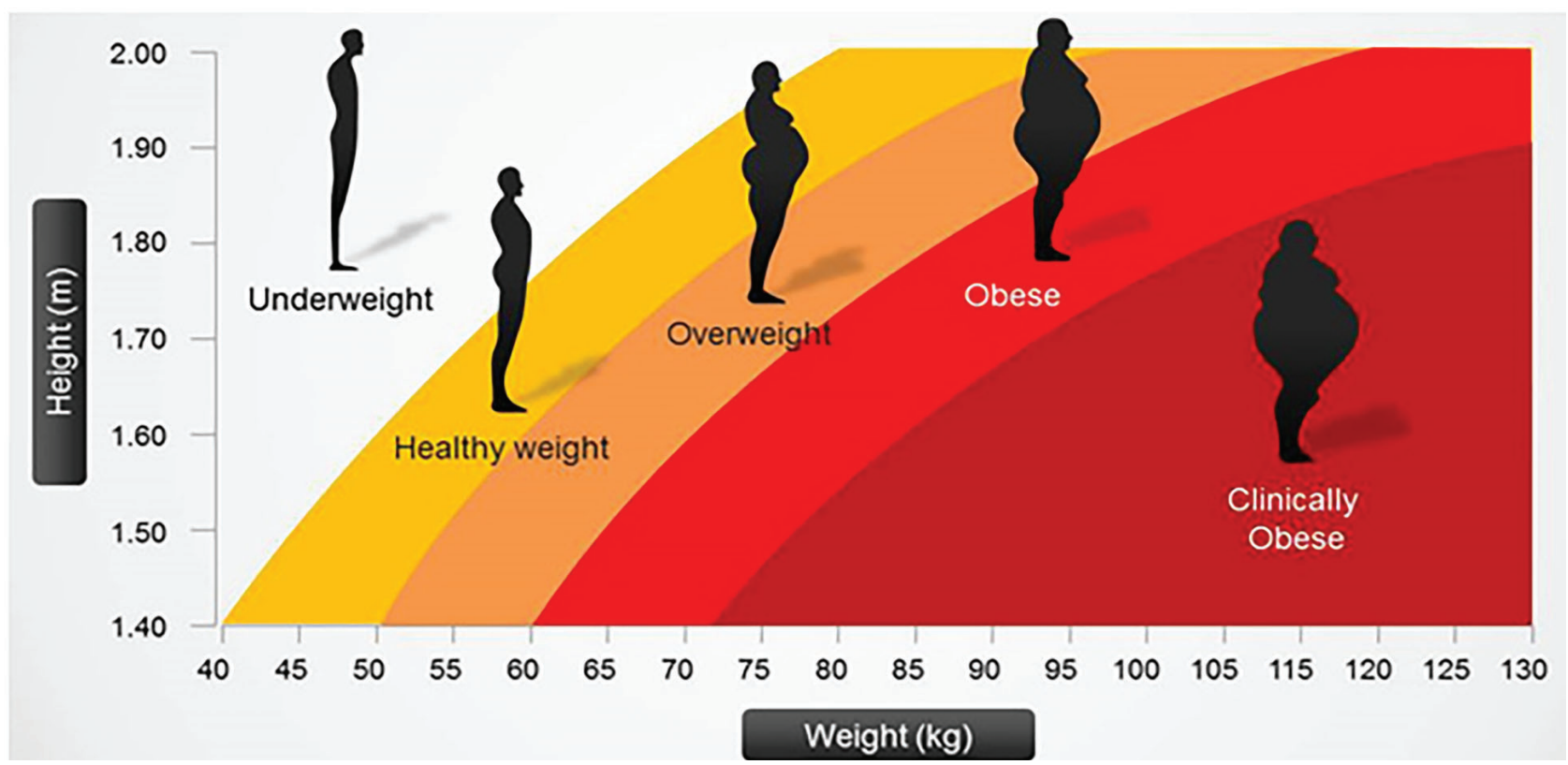

Grafikon 1. BMI kategorije

\section{Rezultati}

Vrijednosti deskriptivne statistike (Tabela 2) ukazuju na izrazitu homogenost tenisera $\mathrm{u}$ svim posmatranim mjerama kod svih analiziranih subuzorka formiranih unaprijed. Veći varijabilitet rezultata primjetan je samo kod mjere Godine, za ispitanike koji su se nalazili na prvih 10 vodećih mjesta u 1976. i 1986. godine što je posljedica velikog raspona rezultata ispitanika u tim kalendarskim godinama.

Tabela 2. Deskriptivni statistici mjera za procjenu morfoloških karateristika cjelokupnog uzorka

\begin{tabular}{lccccccc}
\hline Mjera & Grupa & MIN & MAX & A. S. & S. D. & C. V. & S. W. \\
\hline & 1973 & 173 & 193 & 180.90 & 5.76 & 3.18 & 0.42 \\
& 1986 & 178 & 193 & 187.90 & 4.73 & 2.52 & 0.28 \\
Tjelesna visina (cm) & 1996 & 175 & 196 & 186.70 & 6.78 & 3.63 & 0.48 \\
& 2006 & 178 & 196 & 185.30 & 5.74 & 3.10 & 0.41 \\
& 2016 & 175 & 196 & 186.50 & 6.88 & 3.70 & 0.71 \\
& 1973 & 68 & 84 & 75.20 & 5.83 & 7.75 & 0.23 \\
& 1986 & 70 & 85 & 78.50 & 5.23 & 6.66 & 0.22 \\
Tjelesna masa (kg) & 1996 & 73 & 89 & 82.00 & 5.19 & 6.33 & 0.75 \\
& 2006 & 70 & 92 & 82.10 & 6.30 & 7.67 & 0.88 \\
& 2016 & 73 & 91 & 83.10 & 6.28 & 7.56 & 0.55 \\
\hline
\end{tabular}


(nastavak sa prethodne strane)

\begin{tabular}{lccccccc}
\hline Mjera & Grupa & MIN & MAX & A. S. & S. D. & C. V. & S. W. \\
\hline \multirow{4}{*}{ BMI $\left(\mathrm{kg} / \mathrm{m}^{2}\right)$} & 1973 & 21.33 & 24.49 & 22.96 & 1.06 & 4.62 & 0.43 \\
& 1986 & 19.81 & 23.30 & 22.24 & 0.99 & 4.45 & 0.03 \\
& 1996 & 22.01 & 24.84 & 23.53 & 0.90 & 3.82 & 0.92 \\
& 2006 & 21.35 & 24.90 & 23.90 & 1.27 & 5.31 & $0.01^{*}$ \\
& 2016 & 22.07 & 25.75 & 23.88 & 1.08 & 4.52 & 0.97 \\
Godine & 1973 & 21 & 39 & 28.40 & 5.44 & 19.15 & 0.64 \\
& 1986 & 19 & 34 & 24.10 & 4.25 & 17.63 & 0.11 \\
& 1996 & 22 & 29 & 25.20 & 2.39 & 9.48 & 0.14 \\
& 2006 & 20 & 27 & 24.40 & 2.17 & 8.89 & 0.37 \\
& 2016 & 26 & 35 & 30.30 & 2.79 & 9.21 & 0.71 \\
\hline
\end{tabular}

Legenda: A.S. - aritmetička sredina; S.D. - standardna devijacija; MIN-minimalne vrijednosti rezultata mjerenja; MAX-maksimalne vrijednosti rezultata mjerenja; C.V.- koeficijent varijacije; S.W. - Shapiro Wilk test

Vrijednosti stanja uhranjenosti (BMI) za sve tenisere $u$ svim decenijskim periodima ukazuju na izbalansiran odnos između tjelesne mase i tjelesne visine (što je i karakteristično za sportiste), pa se može konstatovati prosječno normalno stanje uhranjenosti kod svih subuzorka ako se u obzir uzme Harisonova klasifikacija (Kristiforović-Ilić, 2004). Na osnovu Shapiro Wilk testa može se uočiti normalnost distribucije u skoro svim mjerama. Odstupanja od normalne distibucije uočene su samo u mjeri BMI kod subuzorka tenisera za period 2006. godine.
Na osnovu dobijenih podataka (Grafikon 2) može se uočiti da su najuspješniji teniseri, bili prosječno najviši 1986. godine $(187.70 \mathrm{~cm})$, a najniži 1976 . godine $(180.90 \mathrm{~cm})$. Primjetan je izuzetan pomak u tjelesnoj visini tenisera u najznačenim periodima. Današnja prosječna visina tenisera napribližnija je teniserima iz 1996. godine. Prosječno najveća tjelesna masa uočena je 2016 . godine $(83.10 \mathrm{~kg})$, dok je najmanja prosječna tjelesna masa bila 1973 . godine $(75.20 \mathrm{~kg})$.

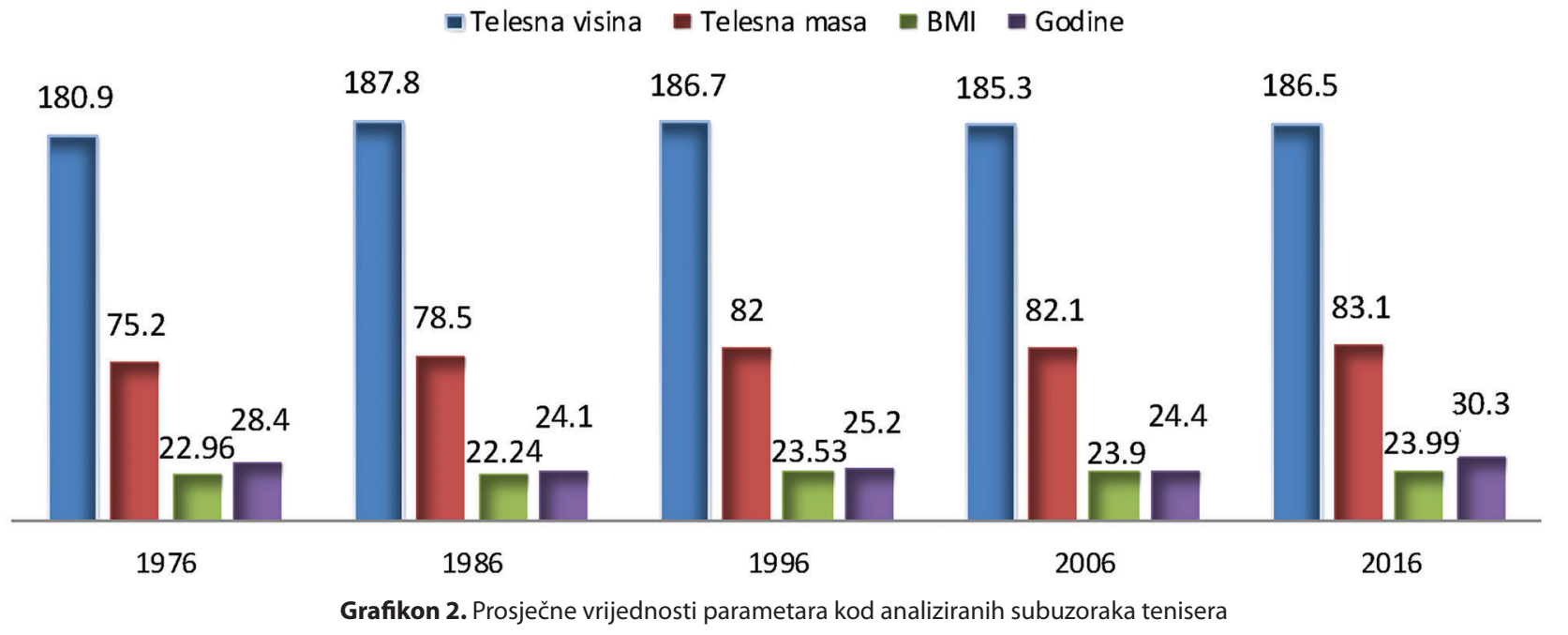

Teniseri različitih perioda se statistički značajno razlikuju (Tabela 3) u mjerama za procjenu mase tijela, Tjelesna masa dine $(\mathrm{p}=0.00)$. U mjeri za procjenu longitudinalnosti skeleta, Tjelesna visina, za razliku od ostalih nije uočena statistički značajna $(\mathrm{p}=0.02)$, stanju uhranjenosti BMI $(\mathrm{p}=0.01)$ i godina starosti, Gorazlika zbog sličnog stanja longitudinalnosti skeleta $(\mathrm{p}=0.11)$.

Tabela 3. Razlike između ispitanika u mjerama za procjenu morfoloških karakteristika (ANOVA)

\begin{tabular}{ccc}
\hline Mjera & $\mathbf{F}$ & $\mathbf{P}$ \\
\hline Tjelesna visina $(\mathrm{cm})$ & 1.99 & .110 \\
Tjelesna masa $(\mathrm{kg})$ & $3.22 *$ & .020 \\
BMI $\left(\mathrm{kg} / \mathrm{m}^{2}\right)$ & $4.33^{*}$ & .010 \\
Godine & $5.67 *$ & .000 \\
\hline
\end{tabular}

Legenda: F - F test; p - nivo statističke značajnosti; * - statistički značajna razlika

Rezultati Bonferoni testa (Tabela 4) pokazuju da postoje između ispitanika iz 1973. i grupa iz 2016. godine ( $\mathrm{p}=0.38$ ). statistički značajne razlike kada je u pitanju tjelesna masa 
Tabela 4. Razlike između ispitanika u različitim vremenskim periodima za tjelesnu masu (Bonferonijevo poređenje)

\begin{tabular}{llcc}
\hline (I) grupa & (J) grupa & Razlika AS (I-J) & p \\
\hline \multirow{3}{*}{ grupa 1973 } & grupa 1986 & -3.300 & 1.000 \\
& grupa 1996 & -6.800 & .117 \\
& grupa 2006 & -6.900 & .106 \\
& grupa 2016 & $-7.900 *$ & .038 \\
grupa 1986 & grupa 1973 & 3.300 & 1.000 \\
& grupa 1996 & -3.500 & 1.000 \\
& grupa 2006 & 33.600 & 1.000 \\
grupa 1996 & grupa 2016 & -4.600 & .821 \\
& grupa 1973 & 6.800 & .117 \\
& grupa 1986 & 3.500 & 1.000 \\
grupa 2006 & -.100 & 1.000 \\
grupa 2006 & grupa 2016 & -1.100 & 1.000 \\
& grupa 1973 & 6.900 & .106 \\
& grupa 1986 & 3.600 & 1.000 \\
grupa 1996 & .100 & 1.000 \\
grupa 2016 & grupa 2016 & -1.000 & 1.000 \\
& grupa 1973 & $7.900 *$ & .038 \\
\hline Legenda: I grupa - podjela tenisera u različitim vremenskim periodima; J grupa - pod- \\
jela tenisera u različitim vremenskim periodima; Razlika AS - razlika u vrijednostima \\
aritmetičkih sredina između dvije grupe: p - nivo statističke značajnosti Bonferonijevog \\
poređenja; * - statistički značajna razlika & & .821 \\
& grupa 1986 & 4.600 & 1.000 \\
& grupa 2006 & 1.100 & \\
& & 1.000 &
\end{tabular}

Rezultati Bonferoni testa (Tabela 5) pokazuju da postoje pe ispitanika iz 1986. i grupa iz 2006. godine (p=0.01) i 2016. statistički značajne razlike kada je u pitanju BMI između gru- godine $(\mathrm{p}=0.01)$.

Tabela 5. Razlike između ispitanika u različitim vremenskim periodima za indeks tjelesne mase (Bonferonijevo poređenje)

\begin{tabular}{llcc}
\hline (I) grupa & (J) grupa & Razlika AS (I-J) & p \\
\hline \multirow{4}{*}{ grupa 1973 } & grupa 1986 & .715 & 1.000 \\
& grupa 1996 & -.565 & 1.000 \\
grupa 2006 & -.937 & .558 \\
grupa 1986 & grupa 2016 & -.920 & .602 \\
& grupa 1973 & -.715 & 1.000 \\
& grupa 1996 & -1.280 & .102 \\
grupa 1996 & grupa 2006 & $-1.652^{*}$ & .012 \\
& grupa 2016 & $-1.634^{*}$ & .013 \\
& grupa 1973 & .564 & 1.000 \\
grupa 2006 & grupa 1986 & 1.280 & .102 \\
& grupa 2006 & -.371 & 1.000 \\
& grupa 2016 & -.354 & 1.000 \\
& grupa 1973 & .936 & .558 \\
grupa 2016 & grupa 1986 & $1.652^{*}$ & .012 \\
& grupa 1996 & .371 & 1.000 \\
& grupa 2016 & .017 & 1.000 \\
& grupa 1973 & .919 & .602 \\
& grupa 1986 & $1.634 *$ & .013 \\
& grupa 1996 & .354 & 1.000 \\
& grupa 2006 & -.017 & 1.000 \\
\hline
\end{tabular}

Rezultati Bonferoni testa (Tabela 6) pokazuju da postoje grupe 1986. i grupe 2016. (p=0.01), pri čemu su ispitanici iz statistički značajne razlike kada su u pitanju godine između 1986. godine prosječno bili mlađi za 6 godina. 
Tabela 6. Razlike između ispitanika u različitim vremenskim periodima varijabla godina (Bonferonijevo poređenje)

\begin{tabular}{lccc}
\hline (I) grupa & (J) grupa & Razlika AS (I-J) & p \\
\hline & grupa 1986 & 4.300 & .111 \\
grupa 1973 & grupa 1996 & 3.200 & .550 \\
& grupa 2006 & 4.000 & .177 \\
& grupa 2016 & -1.900 & 1.000 \\
grupa 1986 & grupa 1973 & -4.300 & .111 \\
& grupa 1996 & -1.100 & 1.000 \\
& grupa 2006 & -.300 & 1.000 \\
grupa 1996 & grupa 2016 & $-6.200 *$ & .004 \\
& grupa 1973 & -3.200 & .550 \\
grupa 1986 & 1.100 & 1.000 \\
grupa 2006 & grupa 2006 & .800 & 1.000 \\
& grupa 2016 & $-5.100 *$ & .030 \\
& grupa 1973 & -4.000 & .177 \\
& grupa 1986 & .300 & 1.000 \\
grupa 1996 & -.800 & 1.000 \\
& grupa 2016 & $-5.900 *$ & .007 \\
& grupa 1973 & 1.900 & 1.000 \\
& grupa 1986 & $6.200 *$ & .004 \\
& grupa 1996 & $5.100 *$ & .030 \\
& grupa 2006 & $5.900 *$ & .007 \\
\hline
\end{tabular}

Razlike takođe postoje između ispitanika Grupe 2006. i Grupe 2016. ( $\mathrm{p}=0.01)$, pri čemu su ispitanici iz 2006. godine bili prosječno mlađi od ispitanika iz 2016. godine i to za skoro 6 godina (5.90 godina).

U ostalim analiziranim mjerama statistički značajne razlike između grupa nijesu bile primjetne zbog sličnih rezultata.

\section{Diskusija}

Primijenjeno istraživanje je imalo za cilj da utvrdi određene razlike u pogledu morfoloških karakteristika najuspješnijih tenisera (prvih 10 na ATP listi) u proteklih 40 godina što je podrazumijevalo ukupno 50 tenisera, ističući osnovne antropometrijske karakteristike uz starosno doba i indeks tjelesne mase koji je izračunat na osnovu prikupljenih podataka visine i mase tijela. Razlike su uočene, a najviše se odnose na BMI i godine starosti tenisera. Nije bilo statistički značajnih razlika u mjeri za procjenu longitudinalnosti skeleta (Tjelesna visina) iako je ona bila dosta veća u odnosu na 1976 . godinu kada su zabilježene najniže prosječne vrijednosti. Nakon 1980. godine, očito je došlo do akcentovanja selekcije tenisera u pravcu longitudinalnosti skeleta, čemu je mogla da doprinese i sama evolucija čovječanstva, gdje su i ljudi današnjice prosječno viši u odnosu na neke ranije periode (Rakić, 2009).

Posmatrajući tenis sa evolutivnog stanovništva može se uvidjeti da je za dostizanje i opstajanje među 10 najboljih na svijetu potrebno vrijeme, iskustvo igranja tenisa, jer se danas teniseri odlikuju prosječnom starošću od $30.3 \pm 2.79$ godine, što je ubjedljivo najviše u odnosu na prethodne tenisere u proteklih 40 godina. Najuspješniji teniseri su u toku 2016. godine imali najveći prosjek godina (30.30 godina), dok su najmlađi bili 1986. godine (24.10 godina). Ovdje se uočavaju i najveće razlike između subuzoraka. Ovo može biti posljedica adekvatnijih i bolje isplaniranih, stručno vođenih trenažnih sadržaja, iskustava trenera u radu sa profesionalnim igračima i adekvatnija rehabilitacija tenisera današnjice. Iako su turniri veoma naporni, veliki broj tenisera, koji su među deset najboljih na planeti, u prosjeku je stariji nego što je to bio slučaj sa ranijim periodima razvoja teniske igre. Kroz istoriju bilo je igrača koji su završavali rangirani među deset najboljih na svijetu sa samo jednim osvojenim Grand Slam turnirom u toku godine i to im je obezbijeđivalo dovoljan broj poena da se nađu na kraju godine među 10 najboljih, a bili su mlađi od 25 godina (npr. Lejton Hjuit, Majkl Čeng). Danas, sistem bodovanja turnira se promijenio i sada je takav da obavezuje tenisere da se pojavljuju na svim većim turnirima tipa ATP 500 ili 250, turnirima iz serije Mastera, Grand Slamovima, jer u protivnom gube poene koje su stekli u prethodnoj sezoni. Iz ovoga proizilazi da je sistem bodovanja možda uticao na ovakve promjene $u$ godinama starosti u odnosu na prethodne etape. Ovakav način bodovanja primorava tenisere da rade kvalitetnije i biraju turnire na kojima će nastupati.

Sa obzirom da vrijednosti BMI proističu iz vrijednosti tjelesne mase i tjelesne visine, rezultati veće varijabilnosti rezultata i odstupanja od normalne distribucije kod subuzorka iz 2006. godine ukazuju na veće razlike u tjelesnoj građi tenisera te godine. Uočene niže vrijednosti BMI indeksa kod ranijih grupa tenisera iz 1986. godine u odnosu na 2006. i 2016. mogu biti posljedica drugačije morfološke građe tenisera. Tjelesna masa i tjelesna visina tenisera su bile nižih vrijednosti nego danas (1986. godine prosječna masa iznosila je $75.2 \mathrm{~kg}$, deset godina kasnije $78.5 \mathrm{~kg}$, 1996. i 2006. oko $82 \mathrm{~kg}$ i 82,1 kg). Danas je prosječna tjelesna masa elitnih profesionalnih tenisera najviša u poslednjih 40 godina i iznosi $83.1 \mathrm{~kg}$. Veća masa može da doprinese većoj silini udaraca, snazi koja je neophodna za moderan tenis. Može se konstatovati porast tjelesne mase tenisera, ali uz normalan, izbalansiran obim uhranjenosti (BMI). U zadnjih desetak godina, tjelesna masa tenisera se povećala (ali ostala u granicama normalnog obima uhranjenosti), što ide vjerovatno na račun povećanja mase mišića. Praktična vrijednost rada se ogleda u dobijenim podacima na uzorku vrhunskih tenisera (po 10 najboljih u periodu od 1976. do 2016. godine) u periodu od 40 godina. Postavlja se pitanje 
za dalja istraživanja koje je optimalno vrijeme za ulazak teniskih igrača među prvih 10 na svijetu i koliko je njegovo vrijeme zadržavanja među njima najduže moguće, pošto Novak Đoković iz dana u dan obara i postavlja nove rekorde, primoravajući ostale igrače da igraju na mnogo višem nivou. $\mathrm{U}$ ovom istraživanju uočene su statistički značajne razlike $\mathrm{u}$ mjerama Tjelesna masa $(\mathrm{p}=0.02)$, stanje uhranjenosti BMI; $(\mathrm{p}=0.01)$ i godina starosti Godine $(\mathrm{p}=0.00)$; Ispitanici grupe tenisera iz 1986. godine su imali prosječno niže i statistički značajnije vrijednosti BMI u odnosu na ispitanike iz Grupe 2006 i Grupe 2016; Uočeno je da su ispitanici iz perioda 1986. godine bili statistički značajno mlađi u odnosu na ispitanike iz 2016. godine. Tjelesna visina se dosta povećala u svim etapama u odnosu na prosječne vrijednosti iz 1976. godine, kada je bila najniža, što govori o pravcu selekcije tenisera na osnovu longitudinalnosti skeleta.

U budućim istraživanjima ovoga tipa potrebno je istražiti i dužinu teniskog staža, odnosno ulazak na ATP listu tenisera i dužinu igranja profesionalnog tenisa, jer bi ona mogla da utiče na godine igrača i njihovo iskustvo. Danas se igrači tenisa odlikuju najvišim prosjekom života. Današnji savremeni profesionalni sport je postao dosta surov i traži od tenisera maksimalna naprezanja i konstatno takmičenje iz nedjelje $\mathrm{u}$ nedjelju, što može dovesti do većih broja povreda, kao posljedica neadekvatnog odmora (Lyons Al-Nakeeb, Hankey, \& Nevill, 2013). Međutim, trenažna opterećenja, dijagnostika i kontrola treniranosti očito prevazilaze ove prepreke i omogućavaju duže bavljenje ovim sportom na veoma visokom nivou.

Limitiranost istraživanja je nedovoljan broj morfoloških parametara među koje se mora uvrstiti transferzalna dimenzionalnost skeleta, volumen i masa tijela i veličine kožnih nabora. U budućim istraživanjima, rezultati navedenih parametara bi bili od velike koriste stručnjacima iz ove oblasti kako bi selekciju mogli još adekvatnije primijeniti što bi pomoglo da se dobiju još kvalitetniji igrači. Ali ipak to ne umanjuje značajnost ove studije, jer bi ovaj rad mogao dati prilog antropološkim disciplinama poput biološke antropologije tenisa, sportskog treninga, a on bi se ogledao $u$ analizi stanja pojedinih morfoloških karakteristika. Prije svega treba da pomogne stručnjacima iz oblasti tenisa da veću pažnju posvete selekcionisanju djece za ovaj sport na osnovu morfoloških karakteristika. Tu se prije svega misli na tjelesnu visinu, ako su u pitanju mlađi igrači. Takođe je interesantno dodati kako je primijećeno da igračko iskustvo igra veoma važnu ulogu u vrhunskom tenisu što je svakako podatak koji će teniskim stručnjacima biti od koristi.

\section{Acknowledgements}

There are no acknowledgements.

\section{Conflict of Interest}

The authors declare that there are no conflicts of interest.

Received: 1 January 2019 | Accepted: 11 March 2019 | Published: 19 April 2019

\section{References}

Arifi, F., Bjelica, D., \& Masanovic, B. (2019). Differences in anthropometric characteristics among junior soccer and handball players. Sport Mont, 17(1), 45-49. doi: 10.26773/smj.190208

Armenulić, R. (2001). Teniski trener. Beograd: Sportska knjiga.

Bala, G. (2000). Zavisnost definisanja modela morfoloških dimenzija od manifestnih antropometrijskih varijabli. Glanik Antropološkog društva Jugoslavije, 35, 95-102.

Castellani, A., D' Aprile, A., \& Tamorri, S. (1992). Tennis Training. Allenamento tecnico, fisico, mentale, esercitazioni e programmi, aspetti biologici. Roma: Societa' stampa sportiva.

Crespo, M. \& Miley, D. (1999). Advanced Coaches Manual. London: ITF

Fernandez, J., Mendez-Villanueva, A., \& Pluim, B.M. (2006). Intensity of tennis match play. Britisch Journal of Sports Medicine, 40(5), 387-391.

Friščić, V. (2004). Tenis bez tajni. Zagreb: Biblioteka Tenis.

Girard, O., \& Millet, G.P. (2004). Effects of ground surface on the physiological and technical responses in young tennis players. In: A. Less, J.F. Kahn, I.W. Maynard (Eds.) Book of Proceedings "Science and recket sports III" (4348). London: Routledge.

Janković, G. (2011). Dijagnostika funkcionalnih i antropometrijskih karakteristika tenisača. U V. Findak (Ur.) Zbornik radova "20. Ljetna škola kineziologa Republike Hrvatske - Dijagnostika u područjima edukacije, sporta, sportske rekreacije i kineziterapije" (291-295). Poreč: Hrvatski kineziološki savez.

Kristoforović-llić, M. (2004). Higijena-priručnik sa parktikumon. Novi Sad: Medicinski fakultet.

Lyons, M., Al-Nakeeb, Y., Hankey, J., \& Nevill, A. (2013). The Effect of Moderate and High-Intensity Fatigue on Groundstroke Accuracy in Expert and Non-Expert Tennis Players Sports. Science Medicine, 12(2), 298-308.

Masanovic, B., Corluka, M., \& Milosevic, Z. (2018). Comparative Study of Anthropometric Measurement and Body Composition of Junior Socce and Handball Players from the Serbian National League. Kinesiologia Slovenica, 24(3), 37-46.

Masanovic, B., Milosevic, Z., \& Corluka, M. (2018). Comparative Study of Anthropometric Measurement and Body Composition between Junior Handball and Volleyball Players from Serbian National League. International Journal of Applied Exercise Physiology, 7(4), 1-6. https://doi. org/10.30472/ijaep.v7i4.313

Novak, D., Milanović, D., \& Barbaros-Tudor, P. (2015). Differences among Tennis Players Aged 12, 14 And 16 Years in Certain Morphological Characteristics: A Croatian Prospective. Collegium Antropologicum, 39(3), 591599.

O'Donoghue, P., \& Ingram, B. (2001). A notational analysis of elite tennis strategy. Journal of Sport Science, 19(2), 107-115.

Popovic, S., Akpinar, S., Jaksic, D., Matic, R., \& Bjelica, D. (2013). Comparative Study of Anthropometric Measurement and Body Composition between Elite Soccer and Basketball Players. International Journal of Morphology, 31(2), 461-7.

Popovic, S., Bjelica, D., Jaksic, D., \& Hadzic, R. (2014). Comparative Study of Anthropometric Measurement and Body Composition between Elite Soccer and Volleyball Players. Int. J. Morphol., 32(1), 267-74.

Rakić, R. (2009). Značaj nekih faktora sredine na rast i razvoj djece i adolescenata u Vojvodini. Neobjavljena doktorska disertacija, Novi Sad: PMF - Departman za biologiju i ekologiju.

Saavedra, J. M., Porgeirsson, S., Kristjansdottir, H., Halldorsson, K., Guðmundsdottir, M. L., \& Einarsson, I. P. (2018). Comparison of training volumes in different elite sportspersons according to sex, age, and sport practised. Montenegrin Journal of Sports Science and Medicine, 7(2), 3742. doi: $10.26773 / \mathrm{mjssm} .180906$

Sánchez-Muñoz, C., Sanz, D., \& Zabala, M. (2007). Anthropometric characteristics, body composition and somatotype of elite junior tennis players. Britisch Journal of Sports Medicine, 41(11), 793-799.

Simić, N. (2004). 303 saveta za vas uspešniji takmičarski tenis. Beograd: CISIM.

Vukasevic, V., Spaic, S., \& Masanovic, B. (2018). Comparative study of anthropometric measurement and body composition between the basketball player first and second league in Montenegro. Journal of Anthropology of Sport and Physical Education, 2(3), 61-65. doi: 10.26773/jaspe.180711 